\title{
Response of Yucca gloriosa "Variegata" to Tissue Culture
}

\author{
Ansam G. Abdul-Halem*' Bushra Alwash" and Kadhim M. Ibrahim ${ }^{* *}$ \\ * Department of Biology, College of Science for Women, Baghdad University. \\ ** Department of Biotechnology, College of Science, Al-Nahrain University. \\ E-mail: ansamg2013@yahoo.com.
}

\begin{abstract}
To explore the potential for in vitro rapid regeneration of Spanish dagger (Yucca gloriosa 'Variegata'), different concentrations of 6-Benzyladenine (BA), 1-naphthaleneacetic acid (NAA) and combinations of both were evaluated for callus induction initiated on leaf and bud (terminal and axillary buds) explants using Murashige and Skoog (MS) medium. Callus response induction percentage, fresh weight, color and texture of the callus were assessed after 1.5 and 6.0 months in culture. The appropriate medium for callus initiation on leaf explants was MS medium supplemented with $6.0 \mathrm{mg} / \mathrm{L}$ NAA. A combination of $0.2 \mathrm{mg} / \mathrm{L} \mathrm{BA}$ and $1.5 \mathrm{mg} / \mathrm{L}$ NAA also exhibited a remarkable callus induction on bud explants. Effect of thidiazuron (TDZ) addition to the culture medium supplemented with BA and NAA at various concentrations $(0.0,0.1,0.5$ or 1.0 $\mathrm{mg} / \mathrm{L}$ ) was investigated. Faster callus growth and more callus proliferationon from bud explants were observed in MS medium supplemented with $0.1 \mathrm{mg} / \mathrm{L} \mathrm{BA}+1.5 \mathrm{mg} / \mathrm{L} \mathrm{NAA}+1 \mathrm{mg} / \mathrm{L}$ TDZ Results showed that TDZ was more effective on callus induction than BA or NAA, however some combinations gave direct shoot regeneration. Calli derived from bud explants were whitish to creamy and compact, while calli derived from leaf explants were greenish.
\end{abstract}

Keywords: callus induction, leaf explants, bud explants, Yucca gloriosa, BA, NAA, TDZ.

\section{Introduction}

Medicinal herbs have been used over a long time to be one of the important sources of a new medicines and leading compounds due to their therapeutic effects demonstrated in clinical use [1]. Yucca gloriosa 'Variegata' (Agavaceae) commonly known as Spanish Dagger or Variegated Mound Lily, is a medium-sized, single-stemmed evergreen shrub. The leaves of this plant are stiff, swordshaped, spine-tipped, striped, edged creamy yellow that changed red in the cold months of the year, 2-3 feet long, 2 inches wide, long pointed, and mostly in rosettes at the ground level or at the ends of the trunk. Bell-shaped cream flowers in broad panicles to $2 \mathrm{~m}$ in height appear in late summer and autumn that usually overtop the leaves.

$Y$. gloriosa widely grows in California, Mexico and India [2, 3].

Yucca is a popular plant for indoor decoration. The interest of this plant is increasing because all parts of yucca gloriosa are rich in steroidal compounds. Lots of steroidal glycol-sides including new organic compounds have been isolated from leaves, flowers, and rhizomes. Y. gloriosa L. was used as a source of the sapogenin, tigogenin and for raw material for the synthesis of steroidal hormone and total glycosides from leaves. Dried plants are used to prepare a potential antimycotic substance for external application and some important steroidal saponins have been isolated from leaves and rhizomes that can be used as antiarthritic, purgative and detergent. Also, antifungal activity in vitro was detected in crude extract from $Y$. gloriosa against Candida albicans, $C$. tropicalis, $C$. glabeasa, and C. Kefyr. Propagation of Yucca by cuttings and offsets produces a few plants and it is a very slow growing and does not blossom every year. Micropropagation offers major production and marketing advantages over traditional propagation methods $[4,5,6$, and 7].

Bentzet al. (1998) developed callus from shoot tip explants excised from Yucca glauca on MS medium supplemented with factorial combina-tions of $\alpha$-naphthaleneacetic acid (NAA) at elevated levels $(0.0$ to $3.2 \mu \mathrm{M})$ and 6-benzylaminopurine (BA) at 0.0 to $45 \mu \mathrm{M}$. Shoots were better proliferated with increasing concentra-tions of BA. Callus and poor quality shoots were obtained in the presence of NAA 
and the absence of BA [8]. The callus was produced from shoot tips, tender stem, shoot and leaf segments of Yucca gloriosa L. The induced calli from the stem tip produced best adventitious buds and the optimum media for formation of callus was achieved on MS medium with 6-BA $3.0 \mathrm{mg} / \mathrm{L}+$ NAA $0.2 \mathrm{mg} / \mathrm{L}$ + sucrose $30 \mathrm{~g} / \mathrm{L}$ [9]. Subsequently, Yangdong et al. (2012) disclosed a tissue culture method and a special culture medium of a Spanish dagger anther. A callus induction culture medium was a solid culture medium obtained by adding $4.5-5.5 \mathrm{mg} / \mathrm{L}$ 6-BA, 0.2-0.4 mg/L Kinetin, 0.4-0.6 mg/L NAA, a carbon source, and jellies into MS basic culture fluid. The response for callus induction of the Spanish dagger anther recorded $22.7 \%$ [10]. Furthermore, Yong-qin et al. (2012) initiated callus tissue from in vitro culture from filaments of Yucca gloriosa L. Results showed that the best callus induction medium was MS + 6-BA $5.0 \mathrm{mg} / \mathrm{L}+$ Kinetin $1.0 \mathrm{mg} / \mathrm{L}+2,4-\mathrm{D}$ $0.5 \mathrm{mg} / \mathrm{L}+$ sucrose $30 \mathrm{~g} / \mathrm{L}$ [11].

The present research was designed to develop a rapid procedure for callus induction from two types of explants (leaves and buds) using different types of growth regulators.

\section{Materials and Methods}

Plant material and culture conditions

Leaves and buds (terminal and axillary) segments were taken from plants growing in a greenhouse. They were collected and washed with tap water for $30 \mathrm{~min}$ and then transferred to air flow cabinet, surface sterilized with $70 \%$ ethanol for $30 \mathrm{sec}$, submerged in $4 \%$ Clorox for $15 \mathrm{~min}$ and then rinsed three times with sterile distilled water. Explants were, aseptically, cultured on MS medium with different combinations of plant growth regulators and incubated in a growth chamber at $25 \pm 2{ }^{\circ} \mathrm{C}$ in dark for 1 week and then transferred to light conditions under $16 \mathrm{hrs}$ illuminetion (2000 Lux, daylight fluorescent tubes). Agar was added after adjusting the $\mathrm{pH}$ to (5.8). To determine the best auxin and cytokinin combination, the explants were inoculated in MS medium fortified with different concentrations of BA, NAA and TDZ in three separate experiments. Different concentrations of each plant growth regulator were combined together and they were examined as the following:

A. Callus induction from leaf explants:

Leaf segment explants $1.0 \mathrm{~cm}$ in diameter were cultured on MS medium containing (0.0, $0.5,1.0,2.0$ or $4.0 \mathrm{mg} / \mathrm{L}) \mathrm{BA}$ and $(0.0,1.5$, $3.0,4.5$ or $6.0 \mathrm{mg} / \mathrm{L}) \mathrm{NAA}$ and their combinations and a total of 25 different combinations were examined. After six months, data were recorded as callus fresh weight, dry weight and the callus induction percentage.

B. Callus induction from bud cultures (terminal and axillary buds):

Shoot tips/axillary buds were excised (3$5 \mathrm{~mm}$ ) from aseptic plants using fine sterile forceps with sharp sterile blades and cultured on MS medium supplemented with factorial combinations of $0.1,0.2,0.3$ or $0.4 \mathrm{mg} / \mathrm{L} \mathrm{BA}$ plus $1.0,1.5,2.0$ or $2.5 \mathrm{mg} / \mathrm{L}$ NAA. After six weeks, callus fresh weight was recorded.

C. The medium was supplemented with another type and concentrations $(0.0,0.1,0.5$, $1.0 \mathrm{mg} / \mathrm{L}$ ) of the cytokinin (TDZ) added to the combination of (BA $0.1 \mathrm{mg} / \mathrm{L}+\mathrm{NAA}$ $1.5 \mathrm{mg} / \mathrm{L}$ ) as a control medium for callus induction from terminal and axillary buds by using different types of cytokinins. Ten replicates were used for every type of callus induction medium. A completely randomized design was utilized, means were compared and least significant differences were calculated at 0.05 of probability using statistical analysis system SAS. [17].

\section{Results and Discussion}

Callus fresh weights were influenced by the explants type and the medium protocol. When callus production potential of the two types of Yucca gloriosa explants, it was found that callus masses formed from buds were larger than that obtained from leaf segments Fig.(1).

\section{Callus induction from leaf explants}

Fresh and dry weights responses for callus initiation on leaf explants are displayed in Table (1). While there was a little callus produced on the explants in some combinations, however, no callus initiation was observed during the culture period in the 


\section{Journal of Al-Nahrain University}

\section{Science}

control (that is, basal medium without growth regulators). Also the results displayed in Table (1) show that $\%$ of callus initiation was $10 \%$ in some combinations of BA and NAA after six months while mean reached $100 \%$ at $6.0 \mathrm{mg} / \mathrm{L}$ of NAA. This concentration of NAA had the highest fresh weight reached $214.2 \mathrm{mg}$ and at $4.5 \mathrm{mg} / \mathrm{L} \mathrm{NAA}$, it recorded $168.8 \mathrm{mg}$ of callus obtained on leaf segments with considered the highest initiation ratios $(100 \%$ and $90 \%$ respectively). NAA was more effective than BA or the combination of both on callus induction. Increasing the concentration of the cytokinin and auxin decreased the percentage of explants showed callusing, fresh and dry weight of callus. There were no significant differences among other combinations. All calli observed in these combinations were greenish and bubbly Fig.(1- b, c).

Table (1)

Effect of BA and NAA combinations on fresh weight, dry weight and \% of explants initiating callus on Yucca gloriosa leaf explants after six months of culture on MS medium.

\begin{tabular}{|c|c|c|c|c|}
\hline $\begin{array}{c}N A A \\
(m g / L) \\
\end{array}$ & $\begin{array}{c}B A \\
(m g / L) \\
\end{array}$ & $\begin{array}{c}\text { Percentage } \\
\text { of explants (\%) }\end{array}$ & $\begin{array}{l}\text { Fresh weight } \\
\text { of callus (mg) }\end{array}$ & $\begin{array}{c}\text { Dry weight } \\
\text { of callus (mg) }\end{array}$ \\
\hline 0.0 & 0.0 & 0 & - & - \\
\hline 0.0 & 0.5 & 0 & 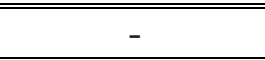 & 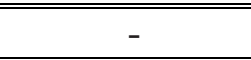 \\
\hline 0.0 & 1.0 & 0 & - & - \\
\hline 0.0 & 2.0 & 0 & - & - \\
\hline 0.0 & 4.0 & 0 & $\begin{array}{l}- \\
\end{array}$ & $\begin{array}{l} \\
\end{array}$ \\
\hline 1.5 & 0.0 & 20 & 81.6 & 8.7 \\
\hline 1.5 & 0.5 & 0 & - & - \\
\hline 1.5 & 1.0 & 0 & - & - \\
\hline 1.5 & 2.0 & 0 & 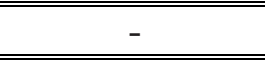 & $\overline{-1}$ \\
\hline 1.5 & 4.0 & 0 & - & - \\
\hline 3.0 & 0.0 & 40 & 88.4 & 10.4 \\
\hline 3.0 & 0.5 & 0 & - & - \\
\hline 3.0 & 1.0 & 0 & $\begin{array}{l}- \\
\end{array}$ & $\begin{array}{l}- \\
\end{array}$ \\
\hline 3.0 & 2.0 & 10 & 132.5 & 32.5 \\
\hline 3.0 & 4.0 & 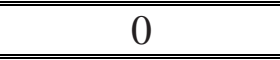 & 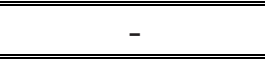 & 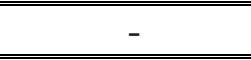 \\
\hline 4.5 & 0.0 & 90 & 168.8 & 28.8 \\
\hline 4.5 & 0.5 & 0 & 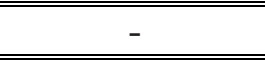 & 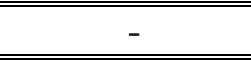 \\
\hline 4.5 & 1.0 & 0 & - & - \\
\hline 4.5 & 2.0 & 20 & 169.8 & 30.8 \\
\hline 4.5 & 4.0 & 10 & 215.7 & 36.5 \\
\hline 6.0 & 0.0 & 100 & 214.2 & 30.6 \\
\hline 6.0 & 0.5 & 40 & 151.7 & 28.3 \\
\hline 6.0 & 1.0 & 30 & 158.2 & 28.4 \\
\hline 6.0 & 2.0 & 30 & 257.8 & 35.8 \\
\hline 6.0 & 4.0 & 0 & 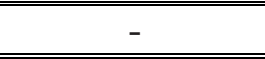 & 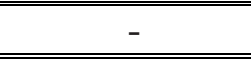 \\
\hline \multicolumn{2}{|c|}{ Means } & 39 & 172.0 & 27.5 \\
\hline \multicolumn{2}{|c|}{$\begin{array}{c}\text { LSD } \\
(\mathrm{P} \leq 0.05)\end{array}$} & $16.483 *$ & $66.2 *$ & $7.9 *$ \\
\hline
\end{tabular}


Table (2)

Effects of BA and NAA combinations on callus fresh weights that induced from bud explants of Yucca gloriosa after six weeks of culture.

\begin{tabular}{|c|c||c||}
\hline NAA $(\mathbf{m g} / \mathbf{L})$ & $\boldsymbol{B A}(\boldsymbol{m g} / \mathbf{L})$ & Fresh weight of callus $(\mathbf{m g})$ \\
\hline \hline 1.0 & 0.1 & - \\
\hline \hline 1.0 & 0.2 & 653.1 \\
\hline 1.0 & 0.3 & - \\
\hline 1.0 & 0.4 & - \\
\hline \hline 1.5 & 0.1 & 2649.8 \\
\hline \hline 1.5 & 0.2 & - \\
\hline \hline 1.5 & 0.3 & - \\
\hline 2.0 & 0.4 & 996.3 \\
\hline \hline 2.0 & 0.1 & 1023.7 \\
\hline 2.0 & 0.2 & - \\
\hline 2.0 & 0.3 & - \\
\hline \hline 2.5 & 0.4 & - \\
\hline 2.5 & 0.1 & 742.9 \\
\hline \hline 2.5 & 0.2 & - \\
\hline 2.5 & 0.3 & - \\
\hline \hline \multicolumn{2}{|c|}{ Means } & 1225.0 \\
\hline \hline LSD $(\mathrm{P} \leq 0.05)$ & $103.5 *$ \\
\hline
\end{tabular}

(-): no callus induction was recorded

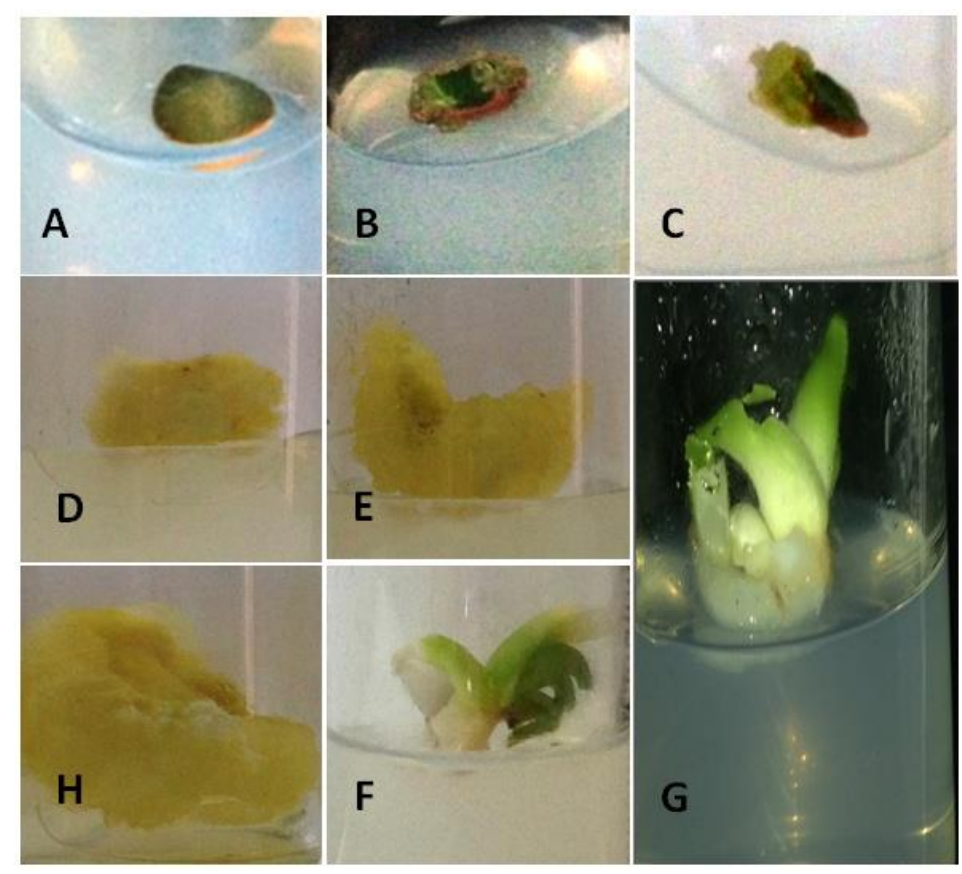

Fig.(1) : In vitro callus induction of Yucca gloriosa. A. The control treatment (basal medium without growth regulators) of leaf explants; $B$. Treatment of leaf explants with low concentrations of BA and NAA; C. Treatment of leaf explants with high concentrations of NAA;

$D$. Treatment of bud explants with $0.1 \mathrm{mg} / \mathrm{L}$ of BA and $1.5 \mathrm{mg} / \mathrm{L} \mathrm{NAA;}$. Treatment of bud explants with $0.2 \mathrm{mg} / \mathrm{L}$ of $B A$ and $1.5 \mathrm{mg} / \mathrm{L} \mathrm{NAA} ; \mathrm{F}$. Treatment of bud explants with $0.1 \mathrm{mg} / \mathrm{L}$ of TDZ, $0.1 \mathrm{mg} / \mathrm{L}$ of $\mathrm{BA}$ and $1.5 \mathrm{mg} / \mathrm{L} \mathrm{NAA}$; G. Treatment of bud explants with $0.5 \mathrm{mg} / \mathrm{L}$ of $\mathrm{TDZ}$, $0.1 \mathrm{mg} / \mathrm{L}$ of $B A$ and $1.5 \mathrm{mg} / \mathrm{L} \mathrm{NAA} ; \mathrm{H}$. Treatment of bud explants with $1 \mathrm{mg} / \mathrm{L}$ of $\mathrm{TDZ}$, $0.1 \mathrm{mg} / \mathrm{L}$ of $B A$ and $1.5 \mathrm{mg} / \mathrm{L} \mathrm{NAA}$. 
Journal of Al-Nahrain University

Science

Callus induction from terminal and axillary buds

During the 6 weeks culture period, the bud explants formed callus at some concentrations of BA and NAA, while no responses after increasing BA and NAA concentrations in the medium. The combination of $0.1 \mathrm{mg} / \mathrm{L} \mathrm{BA}$ and $1.5 \mathrm{mg} / \mathrm{L}$ NAA recorded $1287.9 \mathrm{mg}$ of callus fresh weight Table (2). The response of explants for callus induction was superior at the concentrations $0.2 \mathrm{mg} / \mathrm{L} \mathrm{BA}$ and $1.5 \mathrm{mg} / \mathrm{L}$ NAA and this combination produced 2649.8 mg which was significantly the highest fresh weight in this culture Table (2); Fig.(1E). Browning of the explants was observed at some concentrations but all calli appeared whitish to creamy and all callus textures were compact. Fig. (1) (C, D, and E) exhibits that buds were more responsive for callus induction than leaf segments. It is suggested that $Y$. gloriosa leaves show largely yield and quality of plant fibers. It was found on the microscopic analysis of the leaf that the fiber obtained from $Y$. gloriosa leaves contained sclerenchyma cells [12].

Callus induction from terminal and axillary buds by using different types of cytokinins

Callus induction from buds of Yucca gloriosa demonstrated significant differences in masses of callus, depending on the type and concentration of the cytokinin. Faster callus growth and more callus production were obtained on MS medium supplemented with TDZ. It produced a highest fresh weight of callus (reached $4107 \mathrm{mg}$ ) at $1.0 \mathrm{mg} / \mathrm{L}$ TDZ compared with those cultured on the control medium containing NAA $1.5 \mathrm{mg} / \mathrm{L}+\mathrm{BA}$ $0.1 \mathrm{mg} / \mathrm{L}$. TDZ at 0.1 and $0.5 \mathrm{mg} / \mathrm{L}$ produced direct shoots see Table (3); Fig. (1H, F, G). Similar results were obtained by Atta-Alla and Van Staden (1997) who reported that treatment with TDZ produced excessive callus formation in $Y$. aloifolia [13] and Tawfix and Mohammed (2007) who recorded a high percentage of explants developing callus on a medium containing 4.5 $\mu \mathrm{M}$ TDZ [14]. Bud explants in some concentrations of TDZ produced shoots directly Fig.(1 F, G). Other reports explained that TDZ has similar mechanism to both auxin and cytokinin although, chemically, it is totally different from commonly used auxins and cytokinins. A number of biological (physiological and biochemical) events in cells are indu-ced or enhanced by TDZ. However, a variety of reports showed how morphogenic events are induced by application of TDZ. Other reports showed that TDZ may modify endogenous growth regulators of plant, either directly or indirectly (for example, TDZ treatment could result an increase in endogenous auxin levels which usually stimulate callus formation) and produce reactions in cell/tissue necessary for its division/regeneration [15], modification in cell membrane, energy levels, nutrient absorption, transport and assimilation may be possible [16]. It is concluded from the current study that the callus masses formed from buds are larger than that obtained from leaf segments. Also, treatments with TDZ produce excessive callus formation of Y.gloriosa.

For future works, our work can be extended in different direction for more callus production, low cost or less time; such as: initiate callus from rhizomes that rich with secondary metabolites, using other types of auxins, and using another method for callus induction from leaf segments.

Table (3)

Effects of adding TDZ to MS medium supplemented with a combination of $B A 1.0$ $\mathrm{mg} / \mathrm{L}$ and NAA $1.5 \mathrm{mg} / \mathrm{L}$ on callus fresh weight induction from bud explants after three weeks of culture.

\begin{tabular}{||c||c|c|c||}
\hline $\begin{array}{c}B A \\
(m g / L)\end{array}$ & $\begin{array}{c}N A A \\
(m g / L)\end{array}$ & $\begin{array}{c}\text { TDZ } \\
(m g / L)\end{array}$ & $\begin{array}{c}\text { Callus fresh } \\
\text { weight } \\
(m g)\end{array}$ \\
\hline \hline 0.1 & 1.5 & 0.0 & 1357 \\
\hline 0.1 & 1.5 & 0.1 & - \\
\hline \hline 0.1 & 1.5 & 0.5 & - \\
\hline \hline 0.1 & 1.5 & 1.0 & 4107 \\
\hline \hline \multicolumn{3}{|c|}{ Means } & 2660 \\
\hline \hline \multicolumn{3}{|c|}{ LSD $(\mathrm{P} \leq 0.05)$} & $323.8 *$ \\
\hline
\end{tabular}

(-): no callus induction was recorded 


\section{References}

[1] Abad M. J., Ansuategui M., and Bermejo $P$. "Active antifungal substances from natural sources", E-Journal of Arkivoc, (7), 116-145, 2007.

[2] Thiede T., Yucca. In: Illustrated Handbook of Succulent Plants: Mononcotyledons, Ed. Eggli, U., Springer Verlag, Heidelberg, 8798, 2001.

[3] Gupta, S., Duraiswamy B., Nataraj S.K.M., Raju R.S., Babu U. V., Kumar S., Porwal O., and Gupta R., "Inhibitory Potential of Yucca Gloriosa L. Extract and Isolated Gloriosaol Isomeric Mixture on Ovalbumin Induced Airway Hyperresponsiveness in Balb/C Mice", E-Journal Clinic. Pharmacol. Biopharmaceut., S2:002. doi:10.4172/2167065X.S2-002, 2014.

[4] Kemertelidze É.P., Benidze M.M., and Skhirtladze A.V., "Steroid Compounds from Yucca gloriosaL. Introduced into Georgia and Their Applications", Pharmaceutical Chemistry Journal, 43(1), 45-47, January 2009.

[5] Kemertelidze E. P., Benidze M. M., and Skhirtladze A. V., "Steroidal glycosides from leaves of Yucca gloriosaL.", Bulletin of the Georglian National Academy of Sciences, 5(1), 158-163, 2011.

[6] Elshafei A. A., Esmaiel N. M., Al-Doss A. A., and Barakat M. N., "An Assessment of the Cultural Capabilities of Clonal Propagation and Molecular Characterization of Yucca elephantipes Cultivars", J. of Medic. Plants Res., 5(13), 2896-2905, July, 2011.

[7] Kräutler B., Kinghorn D. A., and Sahu N. P., "Fortschritte der Chemieorganischer Naturstoffe/ Progress in the Chemistry of Organic Natural Products" A.D. Kinghorn, H. Falk, and J. Kobayashi (Eds.), Vol 92, ISSN: 0071-7886, Springer Wien New York, 175, 2008.

[8] Bentz S. E., Parliman B. J., Talbott H. J., and Ackerman W. L., "Factors affecting in vitro propagation of Yucca glauca", Plant Cell, Tissue and Organ Culture, 14(2), 111120, 1998.

[9] Yi P., Yuexiong Z., Yuanhua L., and Rao M., "Tissue culture in Yucca gloriosa Linnaeus ", Chinese J. of Tropical Agric., 5, 2006 (Abstract).
[10] Yangdong G., Yong-qin Z., and Xin-xin W., "Tissue culture method and special culture medium of Spanish dagger anther", Patents, CN 101861833 B, 1-8, 2012.

[11] Yong-qin Z., Na Z., Xin-xin W., He, Z.; Hong-bo, L.; Bing, Z.; and Yangdong G., "Regeneration systems for in vitro culture of filament and genetic variation analysis of Yucca gloriosa L.", Acta Agrestia Sinica, 52012 (Abstract).

[12] Balaji S., "Physical, chemical mechanical properties of fiber ex-tracted from Yисса gloriosa L.", Research and Reviews: A Journal of Life Sciences, 3(1), 2013 (Abstract).

[13] Atta-Alla H.A, Zaghloul M., Waly A.K., and Ascar F.M., "In vitro shoot proliferation, rooting and establishment of Yucca aloifolia, $Y$. filamentosa, and $Y$. filamentosavar. Variegata", Ann. Agric. Sci. Moshtohor, 35(2), 915-934, 1997.

[14] Tawfik A.A., and Mohamed M.F., "Regeneration of salvia (Salvia officinalis L.) via induction of meristematic callus", In Vitro Cellular and Developmental Biology - Plant, 43(1), 21-27, 2007.

[15] Shen X., Kane M.E., and Chen J., "Effects of genotype, explant source, and plant growth regulators on indirect shoot organogenesis in Dieffenbachia cultivars", In Vitro Cellular and Developmental Biology - Plant, 44(4), 282 - 288, 2008.

[16] Guo B., Abbasi B.H., Zeb A., Xu L.L., and Wei Y.H., "Thidiazuron: A multidimensional plant growth regulator", Afric. J. of Biotech., 10(45), 8984-9000, August 2011.

[17] SAS. Statistical Analysis System, User's Guide. Version $9.1^{\text {th }}$ ed. SAS. Inc., Cary. N.C. USA, 2012. 


\section{الخلاصة}

لدراسة إعادة التكوين السريع لنبات الخنجر الاسباني

Yucca gloriosa Variegata تراكيز من منظمات النمو البنزل ادنين BA وحامض النفتالين NAA وبعدة تداخلات من كليهما نم اختبارها لاستحثاث الكالس من الاوراق والبراعم (الطرفية والجانبية) باستعمال الوسط الغذائي موراثيج وسكوج (MS). سجلت النسبة المئوية لاستحثاث الكالس والوزن الطري ولون وليطئ وبنية الكالس بعد 0، 1 و 7 اثشهر من الزراعة. كان الوسط المثالي

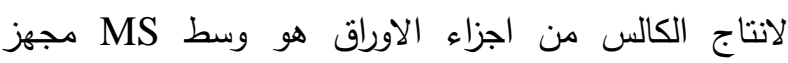

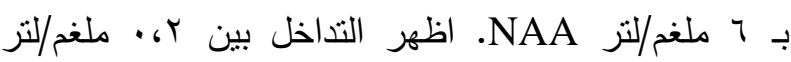

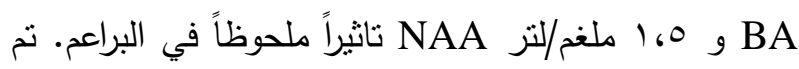

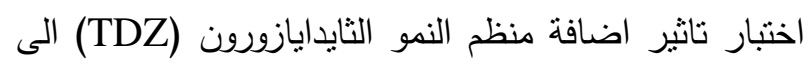

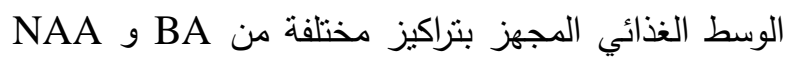

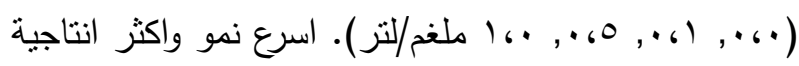

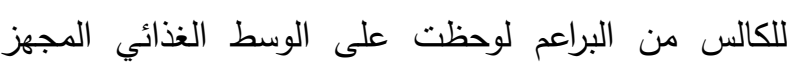

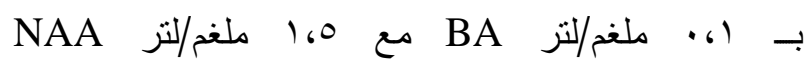

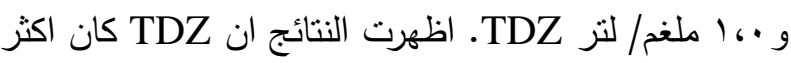
تاثيرا في إستحثاث الكالس من BA او بعض التداخلات اعطت تكوين مباشر للافرع الخضرية. تميز لون كالس البراعم أبيض الى كريمي اللون ومتراص, بينما كان كالس الاوراق اخضر اللون ومفصص. 